\title{
1-O-Alkylglyceryl Ether Lipids of the Gut Walls and Contents of an Abyssal Holothurian (Oneirophanta mutabilis)
}

\author{
Vera L. C. S. Santos ${ }^{*, a, c}$, David S. M. Billett ${ }^{b}$ and George A. Wolff ${ }^{a}$ \\ ${ }^{a}$ Oceanography Laboratories, Department of Earth Sciences, University of Liverpool - UK \\ ${ }^{b}$ Southampton Oceanography Centre, Empress Dock, Southampton - UK \\ ${ }^{c}$ Instituto de Química da Universidade Federal da Bahia, Campus Universitário de Ondina - Ondina, 40170-280 \\ Salvador - BA, Brazil
}

\begin{abstract}
Um estudo de éter de glicerol foi realizado nos lipídios livres da membrana e do conteúdo do aparelho digestivo de uma espécie de holothuria abissal, Oneirophanta mutabilis. Foi detectada uma série desses compostos, saturados e insaturados, variando de $\mathrm{C}_{15} \mathrm{a} \mathrm{C}_{21}$, totalizando de $5-12 \%$ dos lipídios das amostras investigadas. Tanto as amostras das membranas quanto às dos conteúdos analisadas mostraram composições similares, sendo $\mathrm{C}_{16: 0}, \mathrm{C}_{16: 1}, \mathrm{C}_{17: 0}, \mathrm{C}_{18: 0}$ e $\mathrm{C}_{18: 1}$ os componentes principais e, entre eles, $\mathrm{C}_{18: 0}$ o composto dominante para essa espécie de holoturia. $\mathrm{O}$ teor do carbono orgânico total (TOC) e de nitrogênio $(\mathrm{N})$ também foram avaliados nas amostras de conteúdos do trato digestivo e decresceram do esôfago para o reto. A média da eficiência de assimilação média foi estimada em 40 e $55 \%$ para TOC e $\mathrm{N}$ respectivamente
\end{abstract}

A study of the glyceryl ether composition of free lipids of gut walls and contents of an abyssal holothurian species, Oneirophanta mutabilis has been carried out. A series of saturated and unsaturated 1-O-alkylglyceryl ethers with alkyl side chains ranging from $\mathrm{C}_{15}$ to $\mathrm{C}_{21}$ were detected inthe gut walls and contents of $O$. mutabilis. Glyceryl ethers accounted for $5-12 \%$ of the total free lipids contents. Foregut, midgut and hindgut walls and contents have identical 1- $O$-alkylglyceryl ether compositions. The $\mathrm{C}_{16: 0}, \mathrm{C}_{16: 1}, \mathrm{C}_{17: 0}, \mathrm{C}_{18: 0}$ and $\mathrm{C}_{18: 1}$ are the main glyceryl ethers with $\mathrm{C}_{18: 0}$ being dominant. The total organic carbon (TOC) and nitrogen $(\mathrm{N})$ contents were also evaluated in gut contents of the digestive tract of $O$. mutabalis and these decreased from foregut to hindgut. The average assimilation efficiencies were estimated to be 40 and 55\% for TOC and $\mathrm{N}$ respectively.

Keywords: 1-O-alkylglyceryl ether, abyssal sediment, holothurian, Oneirophanta mutabilis, Atlantic Ocean

\section{Introduction}

Glyceryl ethers are widely distributed in nature. Although their biological significance has remained relatively obscure, glyceryl ether lipids have been the focus of investigations in a great variety of samples. A number of reports of glyceryl ethers in human bone marrow, spleen tissue, cow milk, fetal and neotal tissues have been published, ${ }^{1}$ however, glyceryl ethers are more widespread in marine animals than in land animals. For example, alkyl and alk-1'-enyl glycerol monoethers have been identified in elasmobranch fish oils ${ }^{2}$, shark liver oils, fish ${ }^{3}$ and also in marine invertebrates such as sponges ${ }^{4-8}$ oysters, ${ }^{9}$ and several species of Mollusca, Echinodermata and Tunicata. ${ }^{10}$

*e-mail: veraluci@ufba.br
In the class Holothuroidea (Stichopus japonicus, v. armatus and Cucumaria fraudatrix), Isay et al. ${ }^{10}$ identified glyceryl ethers and suggested that these invertebrates might be distinguished by a high $\alpha$-glyceryl ether content (0.9-4.1\% of $\alpha$-glyceryl ethers in total lipid extract). Holothurians are important because they dominate the invertebrate community in large parts of the deep ocean, ${ }^{11}$ and have a substantial influence on other benthic fauna through their feeding, faecal production and even locomotion. They also play an important role in modifying surficial sediments and in structuring the communities that live within it. ${ }^{12,13}$

In this paper we present the results of the examination of glyceryl ethers in free lipids of the gut walls and contents of five specimens of Oneirophanta mutabilis, a species of abyssal holothurian, in order to evaluate quantitatively 
the amount and composition of these compounds and also discuss their possible role in these animals.

\section{Materials and Methods}

\section{Animals description and sample collection}

O. mutabilis (Figure 1A) is a deep-sea holothurian that typically possesses a marked bilateral symmetry, with the ventral and dorsal surfaces clearly distinguishable from each other. Its digestive tract (Figure 1B) descends from the mouth to the opposite extremity of the body, where turning upon itself, it mounts up towards its anterior portion, then turning back again, and once more it passes backwards directly to the anus. ${ }^{14}$
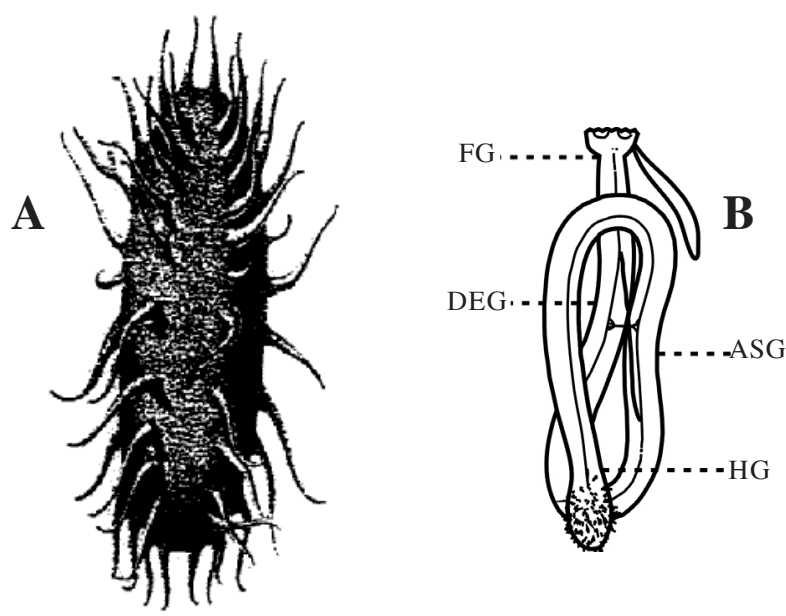

Figure 1. Oneirophanta mutabilis: A - dorsal view; B - digestive tract (FG - Foregut, DEG - Descending midgut, ASG - Ascending midgut, $\mathrm{HG}$ - Hindgut).

All animal samples, kept at $-70{ }^{\circ} \mathrm{C}$ on the ship, were collected from sites on the Porcupine Abyssal Plain (PAP) in the north eastern Atlantic Ocean, at water depths ranging from 4844 to $4845 \mathrm{~m}$.

In the laboratory, gut walls from two animals were washed with Milli-Q water (18 $\mathrm{M} \Omega \mathrm{cm}^{-1}$ resistivity) and were ground in a mortar and pestle. The gut contents from five specimens were freeze dried and stored $\left(-20^{\circ} \mathrm{C}\right)$ prior to lipid extraction.

\section{Determination of assimilation efficiencies}

Assimilation efficiencies were determined by difference between the descending midgut and hindgut contents ${ }^{15}$ for total organic carbon and total nitrogen.
Extraction and analysis of lipids

Lipids in dry gut (walls and contents) samples were extracted using soxhlet apparatus and dichloromethane (DCM, $24 \mathrm{~h}$ ) as solvent. The extracts were evaporated to a small volume under reduced pressure, were quantitatively transferred to a pre-weighed vial, evaporated to dryness under a gentle flow of nitrogen and weighed. A known amount of an internal standard (2,21-dimethyldocosane) was added to the extracts, ${ }^{16}$ which were derivatized immediately prior to analysis with bi-trimethylsilyltrifluoroacetamide (BSTFA) and $1 \%$ of trimethylsilylchloride (TMSCl) $\left(50{ }^{\circ} \mathrm{C}, 1 \mathrm{~h}\right)$ to produce the trimethylsilyl (TMS) derivatives. Blank work-ups were carried out throughout and were analyzed in the same way as for the samples.

Lipid analyses were performed on the derivatized total extract, using a Hewlett Packard 5890-A Gas Chromatograph fitted with an on-column injector, a fused silica capillary column (30 x $0.2 \mathrm{~mm}$ i.d.; cross-linked $5 \%$ phenyl/methyl silicone, HP-5), using helium as carrier gas. The oven temperature was programmed from $40^{\circ} \mathrm{C}$ to $310^{\circ} \mathrm{C}$ at $5^{\circ} \mathrm{C}$ $\mathrm{min}^{-1}$, and held at $310^{\circ} \mathrm{C}$ for $20 \mathrm{~min}$. A retention gap of deactivated silica ( $1 \mathrm{~m} \times 0.32 \mathrm{~mm}$ i.d.) was fitted at the front end of the column. The column was fed directly into the electron impact (EI) source of a VG TS-250 mass spectrometer. The GC-MS operating parameters were as follows: ionization potential $70 \mathrm{eV}$; source temperature 220 ${ }^{\circ} \mathrm{C}$; trap current $300 \mu \mathrm{A}$. The identification of the glyceryl ether compounds was made by comparison of relative retention times and indices and mass spectra of the analytes with literature data. Quantitative data were calculated by comparison of peak areas in the reconstructed total ion current (TIC) chromatogram of the quantification standard (2,21 dimethyldocosane) and the compound of interest. Relative response factors were taken to be equal for all of the analytes, so quantitative data are not absolute. Nevertheless, relative concentrations of the analytes could be compared..$^{13,17-20}$ The precision of the method was determined by replicate analyses $(n=5)$ of one sample and the coefficients of variation of all the determined analytes were less than $11 \%$.

\section{Results and Discussion}

The total organic carbon contents (TOC) and nitrogen (N) values of the gut contents of the foregut (FG), descending midgut (DEG), ascending midgut (ASG) and hindgut (HG) of the five specimens of Oneirophanta mutabilis varied from specimen to specimen, possibly as a result of the varying dietary intake of the individuals 
Table 1. Organic carbon, Nitrogen, $\mathrm{C}: \mathrm{N}$ radio and water contents values in gut contents of Oneirophanta mutabilis

\begin{tabular}{lccrc}
\hline Gut Content & Org. Carbon $(\%)$ & Nitrogen $(\%)$ & C:N ratio & Water content $(\%)$ \\
\hline FG & $4.6 \pm 1.4$ & $0.68 \pm 0.21$ & $6.8 \pm 1.0$ & $70.6 \pm 7.2$ \\
DEG & $2.3 \pm 0.7$ & $0.26 \pm 0.09$ & $9.1 \pm 1.7$ & $80.0 \pm 2.7$ \\
ASG & $2.8 \pm 1.1$ & $0.29 \pm 0.16$ & $10.2 \pm 2.8$ & $79.4 \pm 2.8$ \\
HG & $2.7 \pm 0.8$ & $0.30 \pm 0.13$ & $9.2 \pm 2.2$ & $75.3 \pm 5.4$ \\
\hline
\end{tabular}

(Table 1). The FG contents were consistently richer in carbon and nitrogen than DEG, ASG and HG. These results are consistent with data obtained by Moriarty ${ }^{21}$ for gut contents of Holothuria atra and S. chloronotus and confirm the suggestion that the reduction in value of organic carbon and nitrogen in mid- and hindguts are due to digestive processes and the absorption of metabolic product by the animal.

Assuming that the organic matter in hindgut was originally of similar composition to material which had passed through the foregut, and that the difference between the measured organic carbon and nitrogen values in the gut contents represent organic matter (OM) absorbed by the animal in supplying its own energy, then the amount of organic carbon and nitrogen assimilated by $O$. mutabilis is $c a .40$ and $55 \%$, respectively.

In all of the O. mutabilis specimens, values of the $\mathrm{C}: \mathrm{N}$ ratio in the gut contents were lower in the FG than in the DEG, ASG and HG. Abyssal holothurians are believed to contain abundant bacteria. Furthermore, bacteria are directly associated with the hindgut and may be carried as a resident gut flora. ${ }^{22}$ As nitrogen can be fixed by bacteria associated with the digestive tract, ${ }^{23}$ this may explain the relatively high $\mathrm{C}: \mathrm{N}$ ratio of the hindgut contents.

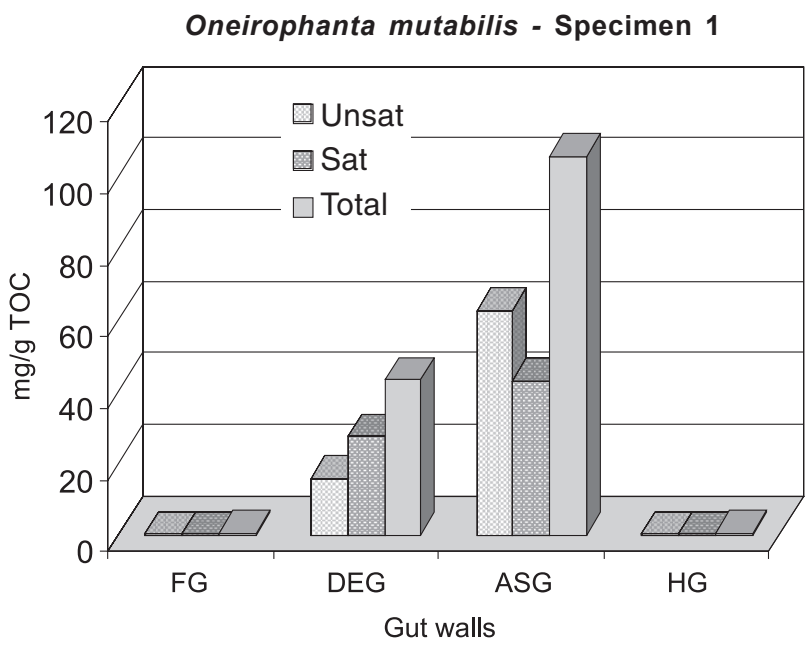

Figure 2. Histograma showing the saturated and unsaturated 1monoalkylglycerol distribution from Oneirophanta mutabilis gut walls - specimem 1.
The TOC of the gut walls of the FG, DEG, ASG and HG of the two specimens of $O$. mutabilis analyzed were high as expected ranging from 22 to $44 \%$ while values of $\mathrm{N}$ ranged from 5 to $10 \%$. The $\mathrm{C}: \mathrm{N}$ ratio was relatively constant (4 - 5) in all samples of gut analyzed.

Total free lipids in gut walls of $O$. mutabilis were analysed and a series of saturated and unsaturated 1-Omonoalkyl glycerols were detected (Figures 2 and 3 ). These comprised ca. 5- $12 \%$ of the total free lipids and ranged from $\mathrm{C}_{15}$ to $\mathrm{C}_{20}$ in carbon number, and are listed according to their hydrocarbon side chains in Tables 2 and 3.

1-Mono-heptadecylglycerol (17:0), 1-mono-9octadecenylglycerol (18:1), and 1-mono-otadecylglycerol (18:0) were the most abundant compounds, the latter being the major component of almost all samples analyzed. However, the unsaturated compounds seem to dominate in the ascending midgut (ASG) and hindgut (HG) in the both of the specimens analyzed.

Glyceryl ethers in $O$. mutabilis gut contents samples comprised about 3-12\% of the total lipids, and were characterised by a series of 1-O-monoalkyl glycerol with similar distributions to those of the gut wall samples.

The saturated and unsaturated 1-mono-alkylglycerols were identified on the basis of their mass spectra, which showed characteristic fragmentation patterns. The base

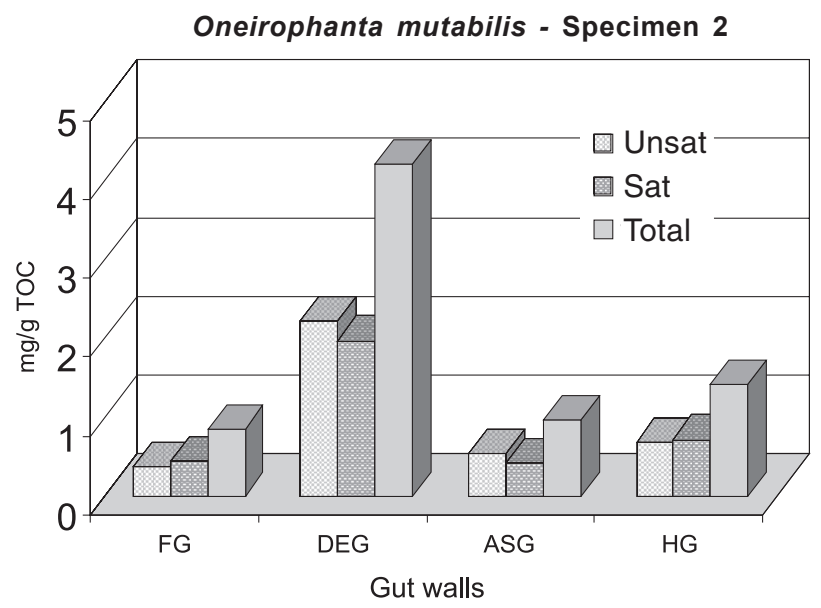

Figure 3. Histograma showing the saturated and unsaturated 1monoalkylglycerol distribution from Oneirophanta mutabilis gut walls - specimem 2 . 
Table 2. Alkylglycerols distribution from gut walls $\left(\mu \mathrm{g} \cdot \mathrm{g}^{-1} \mathrm{TOC}^{\mathrm{a}}\right)$ of the $O$. mutabilis Specimen 1

\begin{tabular}{lrrrr}
\hline Glyceryl ether $^{\mathrm{b}}$ & FG & \multicolumn{1}{c}{ DEG } & \multicolumn{1}{c}{ ASG } & HG \\
\hline $16: 1$ & 50.7 & 1995.2 & 4108.5 & 4.8 \\
$16: 0$ & 19.1 & 1964.0 & 1240.0 & 4.7 \\
$17: 0$ & 81.5 & 5141.3 & 12857.8 & 71.0 \\
$18: 0$ & 151.2 & 17529.0 & 21495.8 & 117.1 \\
$18: 1$ & 160.6 & 9830.8 & 23428.8 & 131.6 \\
$19: 0$ & 32.9 & 2687.2 & 7589.0 & 28.3 \\
$19: 1$ & 44.0 & 884.0 & 10554.7 & 41.0 \\
$20: 1$ & 72.7 & 3129.3 & 24505.2 & 94.8 \\
$20: 0$ & - & 245.2 & - & 2.7 \\
\hline
\end{tabular}

a Values presented are the total of all isomers.

b The glyceryl ethers are represented by the long-chain component of the molecule. The number after the colon denotes the number of double bonds.

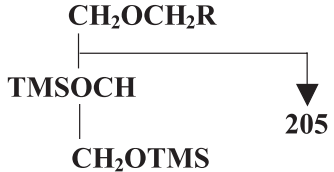

Figure 4. The structural formula of 1-O-alkylglycerol as their TMS ether derivatives showing the characteristic fragmentation patterns $(\mathrm{m} / \mathrm{z}, 205)$

peak $(\mathrm{m} / \mathrm{z}, 205)$ in the mass spectrum of the 1-Oalkylglycerol as their TMS ether derivatives (Figure 4), presumably arises from loss of $\mathrm{C}-1$ of the glycerol with its attached ether group. ${ }^{24}$

The TMS ethers of the unsaturated monoalkylglycerol have a visible $[\mathrm{M}]^{*}$ (molecular ion) and a $[\mathrm{M}-15]^{+}$ion. In contrast, the saturated mono-alkylglycerols showed no molecular ion, but were characterized by a prominent [M$15]^{+}$which arises through elimination of a methyl radical from the trimethylsilyl group..$^{25}$

The origin and biological function of the glyceryl ethers is unclear, however, some authors have suggested that they are important for cell growth, ${ }^{1,2}$ or that they often display important bioactavities ${ }^{4}$ or even that they may have a role in ion transport. ${ }^{26}$ Recently, Smith and Djerassi ${ }^{6}$ isolated alkyl glycerol monoethers from T. aurantia (Sponge). Initially, it was assumed that compounds with the 17:0, iso- and anteiso side chains were derived from bacteria, presumably either by assimilation from dietary sources and/or from the symbiotic microorganisms living in the sponge matrix. However, ${ }^{14} \mathrm{C}$ incorporation experiments with dissociated sponge cells indicated that the alkyl glycerol monoethers were in fact biosynthesised by $T$. aurantia. Smith and Djerassi ${ }^{6}$ therefore suggested that the glyceryl ethers may possess potent antimicrobial
Table 3. Alkylglycerols distribution from gut walls $\left(\mu \mathrm{g} \cdot \mathrm{g}^{-1} \mathrm{TOC}^{\mathrm{a}}\right.$ ) of the $O$. mutabilis Specimen 2

\begin{tabular}{lrrrr}
\hline Glyceryl ether $^{\mathrm{b}}$ & \multicolumn{1}{c}{ FG } & DEG & ASG & \multicolumn{1}{c}{ HG } \\
\hline $15: 0$ & 100.8 & 61.2 & - & 37.5 \\
$16: 0$ & 42.1 & 267.9 & 21.5 & 58.4 \\
$16: 1$ & 115.7 & 540.5 & 79.8 & 109.7 \\
$17: 0$ & 105.1 & 372.7 & 118.0 & 193.3 \\
$18: 0$ & 122.1 & 607.1 & 153.0 & 276.3 \\
$18: 1$ & 157.8 & 1217.4 & 300.9 & 385.1 \\
$19: 0$ & 55.0 & 214.5 & 54.0 & 99.5 \\
$19: 1$ & 46.6 & 257.6 & 80.1 & 100.7 \\
$20: 2$ & 38.0 & 452.1 & 83.9 & 61.0 \\
$20: 1$ & 62.0 & 212.2 & 86.7 & 96.0 \\
\hline
\end{tabular}

${ }^{a}$ Values presented are the total of all isomers.

${ }^{b}$ The glyceryl ethers are represented by the long-chain component of the molecule. The number after the colon denotes the number of double bonds.

properties, affecting both glycerolipid and lipoteichoic acid biosynthesis in Streptococcus mutans.

The gut systems of holothurians including $O$. mutabilis are populated by numerous microorganisms; ${ }^{27}$ hence, the alkylglycerols of $O$. mutabilis, particularly the 17:0 homologue, could originate from bacterial sources. However, alkylglycerol ethers are the precursors of alk-1'enyl glycerol ethers, ${ }^{6}$ and the latter were detected in the ovaries of O. mutabilis (Santos, unpublished data). Hence, it seems likely that the alkylglycerols which are abundant in the gut walls are also biosynthesised by $O$. mutabilis. Such an origin might suggest that they may have a antimicrobial protective function in the gut walls, analogous to that suggested by Smith and Djerassi ${ }^{6}$ for $T$. aurantia. However, further work is required in order to confirm this hypothesis.

\section{Conclusions}

In the Oneirophanta mutabilis, an abyssal holothurian species from PAP, the TOC and N contents was evaluated in gut contents of the its digestive tract decreasing from foregut to hindgut. Average assimilation efficiencies were estimated at 40 and $55 \%$ for TOC and N respectively.

The gut walls and contents of these species of $O$. mutabilis showed glyceryl ether contents of 5-12\% of the total free lipids contents. A series of saturated and unsaturated 1-O-alkylglyceryl ethers ranging from $\mathrm{C}_{15}$ to $\mathrm{C}_{21}$ was identified. Foregut, midgut and hindgut walls and contents of these species analyzed had identical 1-Oalkylglyceryl ether compositions.

It is shown that $\mathrm{C}_{16: 0}, \mathrm{C}_{16: 1}, \mathrm{C}_{17: 0}, \mathrm{C}_{18: 0}$ and $\mathrm{C}_{18: 1}$ are the main components of glyceryl ether distribution of these species and, among them, $\mathrm{C}_{18: 0}$ is dominant. 


\section{Acknowledgements}

V.L.C.S.S. thanks the Conselho Nacional de desenvolvimento Científico e Tecnológico (CNPq) for a scholarship. Financial support from the CEC, through contract MAST-0037-C (EEB), is gratefully acknowledged. We are indebted to two anonymous referees for their useful comments on the original manuscript.

\section{References}

1. Hallgreen, B.; Larsson, S.; J. Lipid Res. 1962b, 3, 39.

2. Hallgreen, B.; Larsson, S.; J. Lipid Res. 1962b, 3, 31.

3. Ohshima T.; Wada S.; Koizumi C.; Lipids 1989, 24, 363.

4. Guella, G.; Mancini, I.; Pietra, F.; J. Chem. Soc. Chem. Commum. 1986,77.

5. Myers, B.C.; Crews, P.; J. Org. Chem. 1983, 48, 3583.

6. Smith, G.M.; Djerassi, C.; Lipids 1987, 22, 4.

7. Cardellina, J.H.; Graden, C.J.; Greer, B.J.; Lipids 1983, 18, 107.

8. Do, M.N.; Erickson, K.L.; Tetrahedron Lett. 1983 , 24, 5699.

9. Koizumi, C.; Jeong, B.Y.; Ohshima T.; Lipids 1990, 25, 363.

10. Isay, S.V.; Mararchenko, M.A.; Vaskovsky, V.E.; Comp. Biochem. Physiol. 1976, 55B, 301.

11. Rice, A. L.; Billet, D. S. M.; Fry, J.; John, A.W.G.; Lampitt, R.S.; Mantoura, R.F.C.; Morris R.J.; Proc. Royal Soc. Edinburgh 1986, 88B, 265.

12. Billett, D.S.M.; Oceanogr. Mar. Biol. Annu. Rev. 1991, 29, 259.

13. Svetashev, V.I.; Levin, V.S.; Ngoklam, C.; Nga, D.T.; Comp. Biochem. Physiol. 1991, 98B, 489.

14. Théel, H.; Report on the Scientific Results of the Exploring Voyage of HMS “Challenger". Zoology, Her Majesty's Stationary Office: London, 1873, p.1882.
15. Roberts, D.; Manship, M.; Moore, H; Horsfall, I; Eardly, D; Santos, V.; Patching, J. ; Wolff. G. A. In Irish Marine Science; Keegan, B.F., O’Connor, R. eds., Galway University Press Ltd.: Galway, 1996, 237.

16. Ginger, M.; Santos, V.; Wolff G.; Journal of the Marine Biological Association, U.K. 2000, 80, 139.

17. Goad, L.J.; Pure Appl. Chem. 1981, 51, 837.

18. Goad, L.J.; Garneau, F.-X.; Simard, J.L.; Apsimon, J.W.; Girard, M.; Comp. Biochem. Physiol., (Part B: Biochem. Mol. Biol.?) 1986, 84B, 189.

19. Santos, V.L.C.S.; PhD Thesis, University of Liverpool, UK, 1993.

20. Santos, V.; Billett, D.S.M; Rice, A.L.; Wolff, G.A.; Deep Sea Research I 1994, 41, 787.

21. Moriarty, D.J.W.; J. Mar. Fresh Water Res. 1982, 33, 255.

22. Deming, J.W.; Colwell, R.R.; Appl. Environ. Microbiol. 1982, 1222.

23. Suchanek, T.H.; Willian, S.L.; Ogden, J.C.; Hubbard, D.K.; Gill, J.P; Deep Sea Research 1985, 32, 201.

24. Wood, G.W. In Complex Lipids Biochemical Applications of Mass Spectometry (first supplementary volum); Georje, R.W.; Otis, C.; Dermer, A. eds.; Willey Intercience Publication, J. Wiley \& Sons, 1980, ch.9.

25. Myher, J.J.; Marai, L.; Kuksis, A.; J. Lipid Res. 1974, 15, 586.

26. Driedzic, W.M.; Selivouchick, D.P.; Roots, B.I.; Comp. Biochem. Physiol. 1976, 53B, 311.

27. Lawson, M.P.; Thompson, J. E.; Djerassi C.; Lipids 1988, 23 , 741.

Received: September 14, 2001

Published on the web: September 24, 2002 